\title{
Michael Cyclization of Polarized Systems: Synthesis and in vitro Anti-Diabetic Evaluation of Some Novel Pyrimidine, Pyridine, Pyrazole and Pyrazolo[3,4- $b$ ]pyridine Derivatives
}

\author{
Essam A. Soylem, Mohammed G. Assy, Ghania M. Morsi*
}

\author{
Department of Chemistry, Faculty of Science, Zagazig University, Zagazig, Egypt \\ * Corresponding author's e-mail address: ghaniamohammed@yahoo.com \\ RECEIVED: March 11, 2017 * REVISED: September 4, 2017 * ACCEPTED: October 13, 2017
}

Abstract: Various interesting heterocycle skeletons were synthesized via Michael type addition reaction with 1,2; 1,3-bidentate nitrogen and carbon nucleophiles. Cycloaddition of different $\alpha, \beta$-unsaturated systems afforded bromopyrimidinone 3/5, bromothiazine 4 and bromopyrazole $6 \mathrm{a} / 6 \mathrm{~b}$ pyrazole-1-carboxylate 8 , pyridinylmethanone 9 , nicotinonitrile 10 , pyrazolopyridine $11 \mathrm{a} / 11 \mathrm{~b}$, pyran-3-carbonitrile 12/13, chromenopyridine 14 and $N$-butyrylpyrazolyl-1-butanone 15 derivatives. The structures of the synthesized compounds were elucidated based on IR, NMR and mass spectral analyses. Group of the newly synthesized compounds were screened for their anti-diabetic activities, whereas compounds 8 and $11 \mathrm{~b}$ exhibited promising anti-diabetic activities at micro molar concentration against $\alpha$-glucosidase inhibitor with $I_{50}$ values ranging between 13.80-500 $\mu \mathrm{M}$. On the other hand compound 10 showed a week effect as compared to the standard anti-diabetic agent.

Keywords: pyrimidine, nicotinonitrile, pyrazolopyridine, chromenopyridine, anti-diabetic.

\section{INTRODUCTION}

$\mathbf{N}$ ITROGEN-containing heterocyclic molecules constitute the largest portion of chemical entities, which are part of many natural products, fine chemicals, and biologically active pharmaceuticals, which are vital for enhancing quality of life. ${ }^{[1-11]}$ In this respect and various approaches for the preparation of these privileged structures with drug-like properties have been developed on various synthetic strategies. Pyrimidines, as the most important nitrogen-containing heterocyclic compounds, are of chemical and pharmacological interest. Many studies have been shown that compounds containing the pyrimidine ring possess antidiabetic, antibacterial, antifungal, antimalarial, and anticonvulsant activities, ${ }^{[12-16]}$ and anticancer activities, ${ }^{[17,18]}$ and many of pyrimidine compounds were reported to act as calcium channel blockers, ${ }^{[19]}$ and as potential central nervous system (CNS) depressants. ${ }^{[20,21]}$ Also, Pyrazoline derivatives widely occur in the environment, in the form of alkaloids, vitamins and pigments as constituents of plant and animal cell. Considerable attention has been carried out on the pyrazolines and substituted pyrazolines due to their inspiring biological activities such as antibacterial, antifungal, ${ }^{[22-24]}$ antidepressant, ${ }^{[25-28]}$ anticonvulsant, ${ }^{[29]}$ and antitumor, ${ }^{[30]}$ properties. The pyrazoline, a versatile moiety is present as the core constituent in a variety of leading drugs such as Sildenafil, Celebrex, and Rimonabant etc. The fact that $\alpha, \beta$-unsaturated carbonyl compounds are push-pull olefins, and Michael acceptors permits them as adaptable intermediates in the synthesis of many azole and azine molecules. ${ }^{[31]}$ Changes in their structure have offered a high degree of diversity that has proven useful for the development of new therapeutic agents having improved potency and lowered toxicity. Based on the above considerations and in continuation of our research on biologically potent heterocyclic derivatives, ${ }^{[32-38]}$ herein, we report the synthesis, structural elucidation and antidiabetic activity of some new azoles and azines prepared from commercially available reagents. 


\section{EXPERIMENTAL}

All melting points were determined using a Stuart melting point apparatus by the open capillary tube method and are uncorrected. IR spectra were recorded on a FT-IR JASCO 6100 instrument in $\mathrm{KBr}$ phase. ${ }^{1 \mathrm{H}} \mathrm{NMR}$ and ${ }^{13} \mathrm{C}$ NMR spectra were recorded on a Varian spectrometer (300 MHz) in DMSO-d6 as solvent, using TMS as internal standard and chemical shifts are expressed as $\delta \mathrm{ppm}$. The mass spectra were recorded by ISQ LT single quadrupole mass spectrometer. In vitro antimicrobial activities were carried out at the Regional Center for Mycology and Biotechnology, Al-Azhar University, Egypt. Elemental analyses were performed by the Micro Analytical Center, Cairo University, Egypt and are within $0.4 \%$ of the theoretical values. The starting materials 2,3-dibromo1,3-diphenylpropan-1-one (1a), 2,3-dibromo-1-(4chlorophenyl)-3-(2-methoxyphenyl)propan-1-one (1b), 1(4-chlorophenyl)-3-(2-methoxyphenyl)prop-2-en-1-one (7a) and 1-(4-chlorophenyl)-3-(2-hydroxyphenyl)prop-2en-1-one (7b) was prepared as described in the literature. ${ }^{[31]}$ The progress of the reaction and the purity of the compounds were routinely monitored on TLC by pre-coated aluminum silica gel $60 \mathrm{~F}_{254}$ thin layer plates obtained from Merck (Germany) eluting with petroleum ether/ethyl acetate. The yields of all products were not optimized. All reagents used were obtained from commercial sources. All solvents were of analytical grade and used without further purification.

\section{Synthesis of Phenyl(2-phenyl-3,4-dihydro- $2 H-1,4-$ benzothiazin-3-yl)methanone (2)}

A mixture of 2,3-dibromo-1,3-diphenylpropan-1-one (1a) (3.68 g, $10 \mathrm{mmol}$ ) and 2-aminobenzenethiol (1.25 g, $10 \mathrm{mmol})$ in methanol $(30 \mathrm{~mL})$ was stirred at r.t. for $30 \mathrm{~min}$, then refluxed for $1 \mathrm{~h}$. After removal of the solvent under vacuum, water was added. The precipitated solid was filtered off, washed with water, dried and recrystallized from methanol to give 2 . Yield $80 \%$ (2.65 g); green crystals; m.p. $160-162{ }^{\circ} \mathrm{C}$; IR (KBr) $\tilde{v} / \mathrm{cm}^{-1}$ : 3347 (NH), 3059, 3025 (CH aromatic), 2922, 2875 (CH aliphatic), 1677 (C=0), 1589 $(\mathrm{C}=\mathrm{C}) ;{ }^{1} \mathrm{H}$ NMR $\left(400 \mathrm{MHz}\right.$, DMSO- $\left.d_{6}\right) \delta / \mathrm{ppm}: 8.31-7.37(\mathrm{~m}$, $14 \mathrm{H}, \operatorname{Ar}-\mathrm{H}), 6.69(\mathrm{~d}, 1 \mathrm{H}, J=11.32 \mathrm{~Hz}, \mathrm{SCH}), 5.78(\mathrm{~d}, 1 \mathrm{H}, J$ $=11.32 \mathrm{~Hz}, \mathrm{CH}-\mathrm{Ar}), 3.61(\mathrm{~s}, 1 \mathrm{H}, \mathrm{NH}) ;{ }^{13} \mathrm{C} \mathrm{NMR}$ spectrum (75 MHz, DMSO-d $d_{6}$ ) $\delta$ / ppm: 192.03, 144.60, 138.84, $137.92,135.13,134.07,133.68,131.18,129.59,129.64$, $129.44,129.31,129.24,128.96,128.46,128.35,127.83$, 122.46, 51.26, 46.77; MS m / z: $333\left(\mathrm{M}^{+}+2\right), 332\left(\mathrm{M}^{+}+\right.$ 1), $331\left(\mathrm{M}^{+}\right), 330\left(\mathrm{M}^{+}-1\right), 229\left(\mathrm{M}^{+}-2\right), 69(100)$; Anal. Calcd mass fractions of elements, $w / \%$, for $\mathrm{C}_{21} \mathrm{H}_{17} \mathrm{NOS}$ $(M r=331.43)$ are: $C, 76.10 ; H, 5.17 ; N, 4.23$. Found: $C$, 76.32; H, 5.34; N, 4.72 .

\section{General Procedure for Synthesis of Pyrimidin-2(1H)-one 3, Thiazine 4, Dihydropyrimidin-2(1H)-one 5, Pyrazole $6 a$ and $6 \mathrm{~b}$ Derivatives}

A mixture of 2,3-dibromo ketone derivative $\mathbf{1 a} / \mathbf{1} \mathbf{b}$ (10 mmol), urea, thiourea, semicarbazide $(0.75 \mathrm{~g}, 10 \mathrm{mmol}$ ) or hydrazine hydrate $99 \%$ (15 mmol) in presence of AcONa $(10 \mathrm{~g})$ in $\mathrm{AcOH}(30 \mathrm{~mL})$ was refluxed for 5-7 hours. Water was added after removal of the solvent under vacuum. The solid precipitated was filtered off, washed with water, dried and recrystallized from the proper solvent to give 3, 4, 5, 6a and $6 \mathbf{b}$, respectively.

\section{5-BROMO-6-(4-CHLOROPHENYL)-4-(2- METHOXYPHENYL)PYRIMIDIN-2(1H)-ONE (3)}

Yield $57 \%$ (2.23 g); green crystals; recrystallized from benzene; m.p. $146-148{ }^{\circ} \mathrm{C}$; IR (KBr) v / $\mathrm{cm}^{-1}$ : $3430(\mathrm{NH})$, 3113, 3063 (CH aromatic), 2925, 2852 ( $\mathrm{CH}$ aliphatic), 1653 $(\mathrm{C}=\mathrm{O}), 1586(\mathrm{C}=\mathrm{N})$; ${ }^{1} \mathrm{H}$ NMR (300 MHz, DMSO-d $\left.d_{6}\right) \delta / \mathrm{ppm}$ : $8.07(\mathrm{~s}, 1 \mathrm{H}, \mathrm{NH}), 8.06-7.06(\mathrm{~m}, 8 \mathrm{H}, \mathrm{Ar}-\mathrm{H}), 3.79(\mathrm{~s}, 3 \mathrm{H}$, $\left.\mathrm{OCH}_{3}\right) ;{ }^{13} \mathrm{C}$ NMR (75 MHz, DMSO-d6) $\delta / \mathrm{ppm}: 189.33$ (C=O), $156.41(\mathrm{C}=\mathrm{N}), 138.01,137.15,134.37,134.03,131.44$, 131.26, 128.80, 124.28, 123.48, 113.65, 111.29 (aromatic carbons), $56.17\left(\mathrm{OCH}_{3}\right) ; \mathrm{MS} \mathrm{m} / \mathrm{z}: 394$ (1.53) $\left(\mathrm{M}^{+}+2\right), 392$ (2.00) $\left(\mathrm{M}^{+}\right)$, 161(100); Anal. Calcd mass fractions of elements, $w / \%$, for $\mathrm{C}_{17} \mathrm{H}_{12} \mathrm{BrClN}_{2} \mathrm{O}_{2}(\mathrm{Mr}=391.64)$ are: $\mathrm{C}$, 52.13; H, 3.09; N, 7.15. Found: $C, 51.91 ; H, 2.99 ; N, 6.82$.

\section{5-BROMO-4-(4-CHLOROPHENYL)-6-(2-METHOXYPHENYL)- 3,6-DIHYDRO-2H-1,3-THIAZIN-2-IMINE (4)}

Yield $67 \%$ ( $2.74 \mathrm{~g})$; yellow crystals; recrystallized from petroleum ether 60 / 80; m.p. $124-126^{\circ} \mathrm{C}$; IR $(\mathrm{KBr}) \tilde{v} / \mathrm{cm}^{-1}$ : $3417(\mathrm{NH}), 2923,2852$ (CH aliphatic), $1658(\mathrm{C}=\mathrm{N}), 1591$ $(\mathrm{C}=\mathrm{C}) ;{ }^{1} \mathrm{H}$ NMR $\left(300 \mathrm{MHz}, \mathrm{DMSO}-d_{6}\right) \delta / \mathrm{ppm}: 8.21-7.04$ (m, $10 \mathrm{H}, \mathrm{Ar}-\mathrm{H}+\mathrm{D}_{2} \mathrm{O}$ exchangeable $\left.\mathrm{NH}\right), 3.88\left(\mathrm{~s}, 3 \mathrm{H}, \mathrm{OCH}_{3}\right), 3.78$ (s, $1 \mathrm{H}, \mathrm{Ar}-\mathrm{CH}) ;{ }^{13} \mathrm{C}$ NMR (75 MHz, DMSO-d6) $\delta / \mathrm{ppm}$ : $187.84,157.34,138.14,136.94,136.07,134.41,131.44$, $130.42,130.24,128.77,125.06,122.58,114.03,113.62$, 112.51, $56.17\left(\mathrm{OCH}_{3}\right), 56.07(\mathrm{ArCH}) ; \mathrm{MS} \mathrm{m} / \mathrm{z}: 411(2.61)\left(\mathrm{M}^{+}\right.$ + 2), 409 (5.64) ( $\left.\mathrm{M}^{+}\right), 69$ (100); Anal. Calcd mass fractions of elements, $w / \%$, for $\mathrm{C}_{17} \mathrm{H}_{14} \mathrm{BrClN}_{2} \mathrm{OS}(\mathrm{Mr}=409.72)$ are: $\mathrm{C}$, 49.83; H, 3.44; N, 6.84. Found: C, 49.52; H, 3.04; N, 6.52.

3-AMINO-5-BROMO-6-(4-CHLOROPHENYL)-4-(2METHOXYPHENYL)-3,4-DIHYDROPYRIMIDIN-2(1H)-ONE (5) Yield $75 \%$ (3.06 g); colorless crystals; recrystallized from petroleum ether 60 / 80; m.p. $162-164{ }^{\circ} \mathrm{C}$; IR (KBr) $\tilde{v} / \mathrm{cm}^{-1}$ : $3450(\mathrm{NH}), 3287,3221\left(\mathrm{NH}_{2}\right), 2962,2928,2846(\mathrm{CH}$ aliphatic), $1677(\mathrm{C}=\mathrm{O}), 1590(\mathrm{C}=\mathrm{C})$; ${ }^{1} \mathrm{H} \mathrm{NMR}(300 \mathrm{MHz}$, DMSO- $\left.d_{6}\right) \delta$ / ppm: 8.23-7.03 (m, 8H, Ar-H), 6.60 (s, 3H, $\mathrm{D}_{2} \mathrm{O}$ exchangeable, $\left.\mathrm{NH}+\mathrm{NH}_{2}\right), 3.76\left(\mathrm{~s}, 3 \mathrm{H}, \mathrm{OCH}_{3}\right), 3.53(\mathrm{~s}, 1 \mathrm{H}$, $\mathrm{CH}$ ); ${ }^{13} \mathrm{C}$ NMR (75 MHz, DMSO-d6) $\delta / p p m: ~ 156.78, ~ 154.33$, 
$145.95,143.95,133.19,131.42,130.38,128.25,127.66$, $126.78,122.41,114.63,112.34,91.68,55.94(\mathrm{ArCH}), 54.90$ $\left(\mathrm{OCH}_{3}\right)$; MS ( $m$ / z, \%): 329, $328\left(\mathrm{M}^{+}-\mathrm{Br}\right), 102$ (100); Anal. Calcd mass fractions of elements, $w / \%$, for $\mathrm{C}_{17} \mathrm{H}_{15} \mathrm{BrClN}_{3} \mathrm{O}_{2}$ $\left(M_{r}=408.67\right)$ are: $C, 49.96 ; \mathrm{H}, 3.70 ; \mathrm{N}, 10.28$. Found: $\mathrm{C}$, 49.79; $\mathrm{H}, 3.81 ; \mathrm{N}, 10.61$.

\section{4-BROMO-3,5-DIPHENYL-1H-PYRAZOLE (6a)}

Yield $83 \%$ (2.48 g); colorless crystals; recrystallized from petroleum ether 60 / 80; m.p. 202-204 ${ }^{\circ} \mathrm{C}$; IR $(\mathrm{KBr}) \tilde{v} / \mathrm{cm}^{-1}$. $3445(\mathrm{NH}), 3095,3063,3003$ (CH aromatic), $1608(\mathrm{C}=\mathrm{N})$, $1578(\mathrm{C}=\mathrm{C}) ;{ }^{1} \mathrm{H}$ NMR (300 MHz, DMSO- $\left.d_{6}\right) \delta / \mathrm{ppm}: 13.35$ (1H, s, $\mathrm{D}_{2} \mathrm{O}$ exchangeable, $\left.\mathrm{NH}\right), 7.89-7.17(10 \mathrm{H}, \mathrm{m}, \mathrm{Ar}-\mathrm{H})$; ${ }^{13} \mathrm{C}$ NMR spectrum (75 MHz, DMSO- $d_{6}$ ) $\delta /$ ppm: 151.34, 143.37 (pyrazole carbons), 133.67, 129.33, 128.93, 128.57, 128.05, 127.39, 125.10, 124.68 (aromatic carbons), 99.54 (C-Br); MS m / z: $301\left(\mathrm{M}^{+}+2\right), 299\left(\mathrm{M}^{+}\right), 223,222\left(\mathrm{M}^{+}-\right.$ $\left.\mathrm{C}_{6} \mathrm{H}_{5}\right), 221,220(100), 219\left(\mathrm{M}^{+}-\mathrm{Br}\right)$; Anal. Calcd mass fractions of elements, $w / \%$, for $\mathrm{C}_{15} \mathrm{H}_{11} \mathrm{BrN}_{2}\left(M_{\mathrm{r}}=299.16\right)$ are: $\mathrm{C}, 60.22 ; \mathrm{H}, 3.71 ; \mathrm{N}, 9.36$. Found: $\mathrm{C}, 60.56 ; \mathrm{H}, 4.01 ; \mathrm{N}$, 9.12 .

\section{4-BROMO-3-(4-CHLOROPHENYL)-5-(2-METHOXYPHENYL)- $1 H$-PYRAZOLE (6b)}

Yield $80 \%$ (2.91 g); colorless crystals; recrystallized from benzene; m.p. $190-192{ }^{\circ} \mathrm{C}$; IR (KBr) $\tilde{v} / \mathrm{cm}^{-1}$ : $3280(\mathrm{NH})$, 3140 (CH aromatic), 2980, 2922, 2838 (CH aliphatic), 1580 (C=N); ${ }^{1} \mathrm{H}$ NMR (300 MHz, DMSO- $\left.d_{6}\right) \delta / \mathrm{ppm}: 7.98-7.10$ (m, $9 \mathrm{H}, \mathrm{Ar}-\mathrm{H}+\mathrm{D}_{2} \mathrm{O}$ exchangeable $\left.\mathrm{NH}\right), 3.92\left(\mathrm{~s}, 3 \mathrm{H}, \mathrm{OCH}_{3}\right) ;{ }^{13} \mathrm{C}$ NMR (75 MHz, DMSO-d6) $\delta$ / ppm: 155.02, 131.95, 131.38, $129.53,128.69,126.71,114.21,112.14,102.84$ (aromatic carbons), $55.84\left(\mathrm{OCH}_{3}\right)$; $\mathrm{MS} m / \mathrm{z}: 365\left(\mathrm{M}^{+}+2\right), 364\left(\mathrm{M}^{+}+\right.$ 1), $363\left(\mathrm{M}^{+}\right), 362\left(\mathrm{M}^{+}-1\right), 361\left(\mathrm{M}^{+}-2\right), 174(100)$; Anal. Calcd mass fractions of elements, $w / \%$, for $\mathrm{C}_{16} \mathrm{H}_{12} \mathrm{BrClN}_{2} \mathrm{O}$ $\left(M_{\mathrm{r}}=363.63\right)$ are: $\mathrm{C}, 52.85 ; \mathrm{H}, 3.33 ; \mathrm{N}, 7.70$. Found: $\mathrm{C}$, 52.52; H, 3.26; N, 7.97.

\section{Synthesis of Tert-butyl 5-(4- chlorophenyl)-3-(2-methoxyphenyl)-2,3- dihydro-1H-pyrazole-1-carboxylate (8)}

A mixture of $7 \mathrm{a}(2.72 \mathrm{~g}, 10 \mathrm{mmol})$, tert-carbazate $(10 \mathrm{mmol})$ in ethanol $(30 \mathrm{~mL})$ was heated under reflux for $5 \mathrm{~h}$. The reaction mixture was concentrated under reduced pressure, cooled and ice cold water was added. The product formed was filtered off, washed with water, dried and recrystallized from petroleum ether 60 / 80 to give 8 . Yield $60 \%$ (2.32 g); yellow crystals; m.p. $136-138{ }^{\circ} \mathrm{C}$; IR $(\mathrm{KBr}) \tilde{v} / \mathrm{cm}^{-1}: 3426(\mathrm{NH}), 3257,3045$ (CH aromatic), 2975, 2928 (CH aliphatic), 1707(C=O), 1604 (C=C); ${ }^{1} \mathrm{H}$ NMR (300 $\mathrm{MHz}$, DMSO- $\left.d_{6}\right) \delta / \mathrm{ppm}: 10.81\left(\mathrm{~s}, 1 \mathrm{H}, \mathrm{D}_{2} \mathrm{O}\right.$ exchangable, $\mathrm{NH}), 8.36-6.93(\mathrm{~m}, 9 \mathrm{H}, \mathrm{Ar}-\mathrm{H}$ and ethenylic $\mathrm{CH}), 3.80(\mathrm{~s}, 3 \mathrm{H}$, $\left.\mathrm{OCH}_{3}\right), 2.18(\mathrm{~s}, 1 \mathrm{H}$, methinyl $\mathrm{CH}), 1.46\left(\mathrm{~s}, 9 \mathrm{H}\right.$, tert-butyl); ${ }^{13} \mathrm{C}$

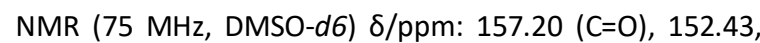

$138.58,130.63,128.14,127.55,125.14,122.71,120.52$, 111.57, 79.20, $55.50\left(\mathrm{~s}, 3 \mathrm{H}, \mathrm{OCH}_{3}\right), 28.03\left(\mathrm{~s}, 9 \mathrm{H}, \mathrm{CH}_{3}\right)$; MS $m$ / z: $389\left(\mathrm{M}^{+}+2\right), 387\left(\mathrm{M}^{+}\right)$, 54(100); Anal. Calcd mass fractions of elements, $w / \%$, for $\mathrm{C}_{21} \mathrm{H}_{23} \mathrm{ClN}_{2} \mathrm{O}_{3}\left(M_{\mathrm{r}}=386.87\right)$ are: $\mathrm{C}, 65.20 ; \mathrm{H}, 5.99 ; \mathrm{N}, 7.24$. Found: C, 64.91; H, 5.88; N, 6.94 .

\section{Synthesis of (4-Chlorophenyl)[6-(4- chlorophenyl)-2,4-bis(2-methoxy- phenyl)-3-pyridinyl]methanone (9)}

A mixture of $7 \mathrm{a}(2.72 \mathrm{~g}, 10 \mathrm{mmol})$ and ammonium acetate $(10 \mathrm{~g})$ in acetic acid $(30 \mathrm{~mL})$ was refluxed for $1 \mathrm{~h}$. After removal of the solvent under vacuum, ice cold water was added and the resultant solution was neutralized with diluted $\mathrm{HCl}$. The solid formed was filtered off, washed with water, dried and recrystallized from methanol to give 9 . Yield $50 \%$ (2.70 g); colorless crystals; m.p. $170-172{ }^{\circ} \mathrm{C}$; IR (KBr) v / $\mathrm{cm}^{-1}$ : 3065 (CH aromatic), 2923, 2830 (CH aliphatic), 1658 $(\mathrm{C}=\mathrm{O}), 1601(\mathrm{C}=\mathrm{N}) ;{ }^{1} \mathrm{H}$ NMR (300 MHz, DMSO- $\left.d_{6}\right) \delta / \mathrm{ppm}$ : 8.27-7.09 (m, 17H, Ar-H and $\mathrm{CH}$ pyridine), $3.83(\mathrm{~s}, 6 \mathrm{H}$, $2 \mathrm{OCH}_{3}$ ); ${ }^{13} \mathrm{C} \mathrm{NMR}(75 \mathrm{MHz}$, DMSO-d6) $\delta / \mathrm{ppm:} 154.48$ (C=O), $148.30(\mathrm{C}=\mathrm{N}), 137.51,134.01,130.50,128.75,128.55$, $120.90,119.64,111.95$ (aromatic carbons), $55.72\left(\mathrm{OCH}_{3}\right)$; $\mathrm{MS}$ m / z: $541\left(\mathrm{M}^{+}\right), 115$ (100); Anal. Calcd mass fractions of elements, $w / \%$, for $\mathrm{C}_{32} \mathrm{H}_{23} \mathrm{Cl}_{2} \mathrm{NO}_{3}\left(M_{\mathrm{r}}=540.43\right)$ are: $\mathrm{C}, 71.12$; $H, 4.29 ; \mathrm{N}, 2.59$. Found: C, 70.82; H, 4.09; N, 2.26.

\section{General Procedure for Synthesis of Nicotinonitrile 10,Pyrazolopyridine 11a and 11b Derivatives}

A mixture of $7 a / 7 b(10 \mathrm{mmol})$ with malononitrile and/or $\mathrm{N}$-phenyl pyrazolone derivative $(10 \mathrm{mmol})$ in acetic acid $(30 \mathrm{~mL})$ in presence of ammonium acetate $(10 \mathrm{~g})$ was refluxed for $10 \mathrm{~h}$. After removal of the solvent under vacuum, water was added and the resultant solution was neutralized with diluted $\mathrm{HCl}$. The precipitated solid was filtered off, washed with water, dried and recrystallized from the proper to give $\mathbf{1 0}, \mathbf{1 1} \mathbf{a}$ and $\mathbf{1 1 b}$, respectively.

\section{2-AMINO-4-(4-CHLOROPHENYL)-6-(2- METHOXYPHENYL)NICOTINONITRILE (10)}

Yield $65 \%$ (2.18 g); recrystallized from acetic acid; orange crystals; m.p. $218-220{ }^{\circ} \mathrm{C}$; IR $(\mathrm{KBr}) \tilde{v} / \mathrm{cm}^{-1}$ : 3449, 3348, $3226\left(\mathrm{NH}_{\text {....NH}}\right.$ ) , 3073, 3026 (CH aromatic), 2970, 2937 (CH aliphatic), 2217 (CN), 1632 (C=N), 1599 (C=C); ${ }^{1} \mathrm{H}$ NMR (300 $\left.\mathrm{MHz}, \mathrm{DMSO}-d_{6}\right) \delta /$ ppm: 8.12-6.93 (m, 9H, Ar-H and $\mathrm{CH}$ pyridine), $3.80\left(\mathrm{~s}, 3 \mathrm{H}, \mathrm{OCH}_{3}\right), 3.36\left(\mathrm{~s}, 2 \mathrm{H}, \mathrm{D}_{2} \mathrm{O}\right.$ exchangable, $\mathrm{NH}_{2}$ ); ${ }^{13} \mathrm{CNMR}$ (75 MHz, DMSO-d6) $\delta$ / ppm: 155.61, 154.71, $149.98,134.02,130.55,130.51,128.53,128.12,127.99$, 125.16, 120.13, 111.13, 55.42, 55.35, 41.06; MS m / z: $338\left(\mathrm{M}^{+}\right.$ $+2), 337\left(\mathrm{M}^{+}+1\right), 336\left(\mathrm{M}^{+}\right), 40(100)$; Anal. Calcd mass fractions of elements, $w / \%$, for $\mathrm{C}_{19} \mathrm{H}_{14} \mathrm{ClN}_{3} \mathrm{O}\left(M_{\mathrm{r}}=335.78\right)$ are: $\mathrm{C}, 67.96$; $H, 4.20 ; N, 12.51$. Found: $C, 67.35 ; H, 4.46 ; N, 12.64$. 


\section{6-(4-CHLOROPHENYL)-4-(2-METHOXYPHENYL)-3-} METHYL-1-PHENYL-1H-PYRAZOLO[3,4-B]PYRIDINE (11a) Yield 75 \% (3.19 g); recrystallized from methanol; yellow crystals; m.p. $178-180^{\circ} \mathrm{C}$; IR (KBr) $\tilde{v} / \mathrm{cm}^{-1}$ : 3073, $3001(\mathrm{CH}$ aromatic), 2954, 2926, 2828 ( $\mathrm{CH}$ aliphatic), 1600 (C=N); ${ }^{1} \mathrm{H}$ NMR (300 MHz, DMSO- $\left.d_{6}\right) \delta /$ ppm: 8.27-7.09 (m, 14H, Ar$\mathrm{H}$ and $\mathrm{CH}$ pyridine), $3.84\left(\mathrm{~s}, 6 \mathrm{H}, 2 \mathrm{CH}_{3}\right) ;{ }^{13} \mathrm{C}$ NMR $(75 \mathrm{MHz}$, DMSO-d6) $\delta$ / ppm: 176.57, 156.33, 154.45, 148.26, 137.48, $133.98,130.46,128.71,128.51,127.08,120.87,120.45$, 119.61, 111.91 (aromatic carbon), $55.69\left(\mathrm{OCH}_{3}\right), 40.33$ $\left(\mathrm{CH}_{3}\right) ; \mathrm{MS} \mathrm{m} / \mathrm{z}: 428\left(\mathrm{M}^{+}+2\right), 427\left(\mathrm{M}^{+}+1\right), 426\left(\mathrm{M}^{+}\right), 131$ (100); Anal. Calcd mass fractions of elements, $w / \%$, for $\mathrm{C}_{26} \mathrm{H}_{20} \mathrm{ClN}_{3} \mathrm{O}\left(M_{\mathrm{r}}=425.90\right)$ are: $\mathrm{C}, 73.32 ; \mathrm{H}, 4.73 ; \mathrm{N}, 9.87$. Found: $C, 73.02 ; \mathrm{H}, 4.33 ; \mathrm{N}, 9.57$.

\section{2-[6-(4-CHLOROPHENYL)-3-METHYL-1-PHENYL-1H-} PYRAZOLO[3,4-B]PYRIDIN-4-YL]PHENOL (11b)

Yield $61 \%$ (2.51 g); recrystallized from methanol / water; brown crystals; m.p. $312-314{ }^{\circ} \mathrm{C}$; IR (KBr) $\tilde{v} / \mathrm{cm}^{-1}$ : 3428 (OH), 3065 ( $\mathrm{CH}$ aromatic), 2859 ( $\mathrm{CH}$ aliphatic), 1601 (C=N); ${ }^{1} \mathrm{H}$ NMR (300 MHz, DMSO- $d_{6}$ ) $\delta / p p m: 11.58$ (s, $1 \mathrm{H}, \mathrm{D}_{2} \mathrm{O}$ exchangable, $\mathrm{OH}), 8.15-7.20(\mathrm{~m}, 14 \mathrm{H}, \mathrm{Ar}-\mathrm{H}$ and $\mathrm{CH}$ pyridine), $2.16\left(\mathrm{~s}, 3 \mathrm{H}, \mathrm{CH}_{3}\right)$; $\mathrm{MS} m / z: 413\left(\mathrm{M}^{+}+2\right), 411\left(\mathrm{M}^{+}\right)$, 83 (100); Anal. Calcd mass fractions of elements, $w / \%$, for $\mathrm{C}_{25} \mathrm{H}_{18} \mathrm{ClN}_{3} \mathrm{O}\left(M_{\mathrm{r}}=411.88\right)$ are: $\mathrm{C}, 72.90 ; \mathrm{H}, 4.40 ; \mathrm{N}, 10.20$. Found: C, 72.15; H, 4.56; N, 9.85.

\section{Synthesis of 6-(4-Chlorophenyl)-4-(2-} hydroxyphenyl)-2-imino-3,4-dihydro- $2 \mathrm{H}$ pyran-3-carbonitrile (12)

A mixture of $7 \mathrm{~b}(2.58 \mathrm{~g}, 10 \mathrm{mmol})$, malononitrile $(0.66 \mathrm{~g}$, $10 \mathrm{mmol})$ and ten drops of TEA in DMF $(30 \mathrm{~mL})$ was heated under reflux for $9 \mathrm{~h}$, and then cooled, poured into ice-cold water and acidified with acetic acid. The precipitated solid was filtered off, dried and recrystallized from methanol to give 12.

Yield $48 \%(1.56 \mathrm{~g})$; brown crystals; m.p. $268-270^{\circ} \mathrm{C}$; $\mathrm{IR}(\mathrm{KBr}) \tilde{v} / \mathrm{cm}^{-1}: 3429(\mathrm{OH}), 3235(\mathrm{NH}), 3074$ (CH aromatic), 2202 (CN), $1601(\mathrm{C}=\mathrm{N})$; ${ }^{1} \mathrm{H}$ NMR $\left(300 \mathrm{MHz}, \mathrm{DMSO}-d_{6}\right)$ $\delta /$ ppm: $8.98(\mathrm{~s}, 1 \mathrm{H}, \mathrm{OH}), 8.86(\mathrm{~s}, 1 \mathrm{H}, \mathrm{NH}), 8.02-7.06(\mathrm{~m}$, $9 \mathrm{H}, \mathrm{Ar}-\mathrm{H}$ and $\mathrm{CH}$ pyran), $3.45(\mathrm{~d}, 1 \mathrm{H}, J=6.9 \mathrm{~Hz}, \mathrm{CH}), 3.40$ $(\mathrm{d}, 1 \mathrm{H}, \mathrm{J}=7.2 \mathrm{~Hz}, \mathrm{CH}) ; \mathrm{MS} m / \mathrm{z}: 326\left(\mathrm{M}^{+}+2\right), 324\left(\mathrm{M}^{+}\right), 323$ $\left(\mathrm{M}^{+}-1\right), 43(100)$; Anal. Calcd mass fractions of elements, $w / \%$, for $\mathrm{C}_{18} \mathrm{H}_{13} \mathrm{ClN}_{2} \mathrm{O}_{2}(\mathrm{Mr}=324.76)$ are: $\mathrm{C}, 66.57 ; \mathrm{H}, 4.03$; $\mathrm{N}, 8.63$. Found: $\mathrm{C}, 66.58 ; \mathrm{H}, 3.96 ; \mathrm{N}, 8.37$.

\section{General Procedure for Synthesis of Pyran-3-carbonitrile 13 and Chromenopyridine 14}

A mixture of $7 \mathbf{b}(2.58 \mathrm{~g}, 10 \mathrm{mmol})$ and/or cyanoacetamide, malonamide (10 mmol) in $50 \mathrm{~mL}$ ethoxide solution [prepared by dissolving $(0.46 \mathrm{~g}, 20 \mathrm{mmol})$ of $\mathrm{Na}$ in $50 \mathrm{~mL}$ abs. ethanol] was heated under reflux for $7 \mathrm{~h}$. After removal of the solvent under vacuum, water was added and the alkaline solution was neutralized with diluted $\mathrm{HCl}$. The product formed was filtered off, washed with cold water, dried and recrystallized from the proper solvent to give $\mathbf{1 3}$ and 14 , respectively.

\section{6-(4-CHLOROPHENYL)-4-(2-HYDROXYPHENYL)-2-OXO-2H- PYRAN-3-CARBONITRILE (13)}

Yield $55 \%$ (1.78 g); green crystals; recrystallized from methanol; m.p. $320-322{ }^{\circ} \mathrm{C}$; IR (KBr) $\tilde{v} / \mathrm{cm}^{-1}$ : $3409(\mathrm{OH})$, 3038 (CH aromatic), 2226 (CN), $1771(\mathrm{C}=\mathrm{O}), 1614(\mathrm{C}=\mathrm{C}) ;{ }^{1} \mathrm{H}$ NMR (300 MHz, DMSO- $\left.d_{6}\right) \delta /$ ppm: $10.10(\mathrm{~s}, 1 \mathrm{H}, \mathrm{OH}), 8.50$ $6.79(\mathrm{~m}, 8 \mathrm{H}, \mathrm{Ar}-\mathrm{H})$; MS m / z: $326\left(\mathrm{M}^{+}+2\right), 325\left(\mathrm{M}^{+}+1\right), 324$ $\left(\mathrm{M}^{+}\right)$, 323(100) $\left(\mathrm{M}^{+}-1\right)$; Anal. Calcd mass fractions of elements, $w / \%$, for $\mathrm{C}_{18} \mathrm{H}_{10} \mathrm{ClNO}_{3}(\mathrm{Mr}=323.72)$ are: $\mathrm{C}$, $66.78 ; \mathrm{H}, 3.11 ; \mathrm{N}, 4.33$. Found: $C, 67.12 ; \mathrm{H}, 3.26 ; \mathrm{N}, 4.65$.

\section{2-(4-CHLOROPHENYL)-4H-CHROMENO[3,4-C]PYRIDINE- 4,5(3H)-DIONE (14)}

Yield $60 \%$ (1.94 g); colorless crystals; recrystallized from acetic acid; m.p. 350-352 ${ }^{\circ} \mathrm{C}$; IR (KBr) $\tilde{v} / \mathrm{cm}^{-1}: 3433(\mathrm{NH})$, 3068, 3035 ( $\mathrm{CH}$ aromatic), 1777, 1638 (C=O), 1616 (C=C); ${ }^{1} \mathrm{H}$ NMR (300 MHz, DMSO-d $\left.d_{6}\right) \delta / p p m: 12.42$ (s, 1H, D 20 exchangable, $\mathrm{NH}), 8.50-7.36(\mathrm{~m}, 9 \mathrm{H}, \mathrm{Ar}-\mathrm{H}$ and $1 \mathrm{H}$, pyridone$\mathrm{H} 1) ; \mathrm{MS} m$ / z: $326\left(\mathrm{M}^{+}+2\right), 325\left(\mathrm{M}^{+}+1\right), 324\left(\mathrm{M}^{+}\right), 323(100)$ $\left(\mathrm{M}^{+}-1\right)$; Anal. Calcd mass fractions of elements, $w / \%$, for $\mathrm{C}_{18} \mathrm{H}_{10} \mathrm{ClNO}_{3}\left(M_{\mathrm{r}}=323.73\right)$ are: $\mathrm{C}, 66.78 ; \mathrm{H}, 3.11 ; \mathrm{N}, 4.33$. Found: $\mathrm{C}, 66.49 ; \mathrm{H}, 3.15 ; \mathrm{N}, 4.52$.

\section{Synthesis of 1-[2-Butyryl-5-(4-} chlorophenyl)-3-(2-hydroxyphenyl)-2,3dihydro-1H-pyrazol-1-yl]-1-butanone (15) A mixture of $7 \mathrm{~b}(2.72 \mathrm{~g}, 10 \mathrm{mmol})$ and hydrazine hydrate 99 $\%(15 \mathrm{mmol})$ in butyric acid $(20 \mathrm{~mL})$ was refluxed for $10 \mathrm{~h}$. The reaction mixture was concentrated under reduced pressure, cooled and neutralized with $5 \%$ sodium carbonate solution. The separated solid was filtered off, washed with water, dried and recrystallized from methanol to give 15. Yield $72 \%$ (2.97 g); yellowish crystals; m.p. 178$180{ }^{\circ} \mathrm{C}$; IR (KBr) v / cm ${ }^{-1}: 3226(\mathrm{OH}), 3190$ (CH aromatic), 2962, 2877 (CH aliphatic), 1638 (C=O), 1594 (C=C); ${ }^{1} \mathrm{H}$ NMR (300 MHz, DMSO- $\left.d_{6}\right) \delta / \mathrm{ppm}: 9.62(\mathrm{~s}, 1 \mathrm{H}, \mathrm{OH}), 7.79-6.67$ (m, 8H, Ar-H), 5.67-5.62 (d, $1 \mathrm{H}, J=4.8 \mathrm{~Hz}$, enaminic $\mathrm{CH}$ ), 3.82-3.72 (t, $4 \mathrm{H}, J=12 \mathrm{~Hz}, 2 \mathrm{COCH}_{2} \mathrm{CH}_{2} \mathrm{CH}_{3}$ ), 3.02-2.94 (d, $1 \mathrm{H}, J=4.8, \mathrm{Ar}-\mathrm{CH}), 2.79-2.63\left(\mathrm{~m}, 4 \mathrm{H}, 2 \mathrm{CH}_{2} \mathrm{CH}_{2} \mathrm{CH}_{3}\right), 0.93(\mathrm{t}$, $\left.6 \mathrm{H}, J=7.5 \mathrm{~Hz}, 2 \mathrm{CH}_{3}\right) ; \mathrm{MS} \mathrm{m} / \mathrm{z}: 415\left(\mathrm{M}^{+}+2\right), 413\left(\mathrm{M}^{+}\right), 370$ (100); Anal. Calcd mass fractions of elements, $w / \%$, for $\mathrm{C}_{23} \mathrm{H}_{25} \mathrm{ClN}_{2} \mathrm{O}_{3}\left(M_{\mathrm{r}}=412.90\right)$ are: $\mathrm{C}, 66.90 ; \mathrm{H}, 6.10 ; \mathrm{N}, 6.78$. Found: $\mathrm{C}, 66.65 ; \mathrm{H}, 5.75 ; \mathrm{N}, 6.45$.

\section{$\alpha$-Glucosidase Inhibitory Assay}

The $\alpha$-glucosidase (Sigma-Aldrich) inhibitory activity was measured according to the method previously described ${ }^{[42]}$ 
with slight modifications. $1 \mathrm{mg}$ of each sample or acarbose at different concentrations $(500 \mu \mathrm{L})$ of $1.0 \mathrm{U} \mathrm{mL}-1$ glucosidase solution in $100 \mathrm{mM}$ phosphate buffer $(100 \mathrm{mM}$, $\mathrm{pH}$ 6.8) at $37{ }^{\circ} \mathrm{C}$ for 20 minutes. The absorbance of the released $p$-nitrophenol was measured at $405 \mathrm{~nm}$. The inhibition percentage was calculated using the given formula: Inhibition \% = Abs control - Abs sample x 100 .

\section{RESULTS AND DISCUSSION}

The heterocyclization of 2,3-dibromo-1,3-diarylpropan-1one $\mathbf{1} \mathbf{a}, \mathbf{b}$ was investigated with the aim of obtaining some better antimicrobial heterocyclic derivatives in a facile route according to the process depicted in scheme 1 . The synthetic strategy for the chemical transformation of dibromo ketone to heterocyclic systems depends upon the base induced dehydrobromination forming $\beta$-bromo unsaturated ketone conjugated addition of reagent nucleophilic center followed by heterocyclization through the loss of $\mathrm{H}_{2} \mathrm{O}$. Thus, Treatment of methanolic solution of 2,3-dibromo-1,3-diphenylpropan-1-one (1a) with 2aminobenzenethiol at room temperature, then heating under reflux afforded the cyclic product 2 . The base mediated nucleophilic attack of thiolate anion to the more electrophilic carbon of dibromo ketone $\mathbf{1}$ followed by thiazine cyclization afforded benzothiazine derivative $\mathbf{2}$. The

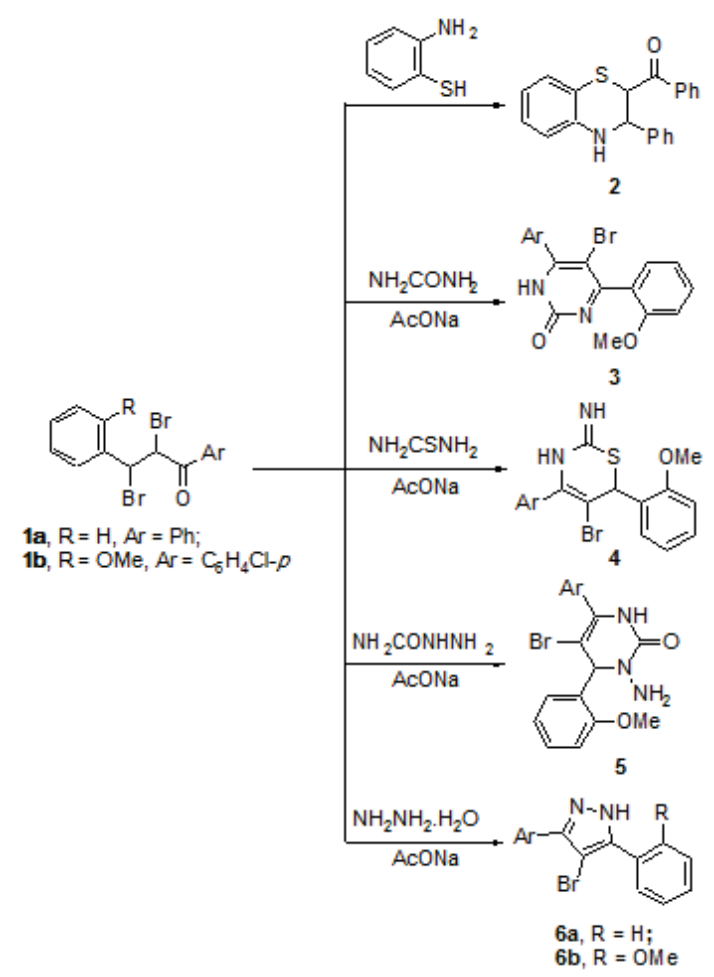

Scheme 1. Utility of $\alpha, \beta$-dibromoketone with bidentate nucleophiles.
IR spectrum of compound 2 revealed the appearance of absorption bands at $3347(\mathrm{NH})$ and $1677(\mathrm{C}=\mathrm{O}) \mathrm{cm}^{-1}$. It's ${ }^{1} \mathrm{H}$ NMR spectrum also showed a singlet at $\delta 3.61 \mathrm{ppm}$ assigned to $\mathrm{NH}$ and two deshielded doublet of doublet at $\delta 6.69,5.78$ ppm attributed for ( $\mathrm{S} \underline{\mathrm{C}} \underline{\mathrm{CO}})$ and $(\mathrm{Ar}-\mathrm{C} \underline{\mathrm{H}})$ protons as well as mass spectrum showed ion peaks at $m / z=333\left(\mathrm{M}^{+}+2\right), 332$ $\left(\mathrm{M}^{+}+1\right), 331\left(\mathrm{M}^{+}\right)$which confirmed their chemical structure.

The [3+3] cyclocondensation of compound $\mathbf{1 b}$ with urea in presence of AcONa via one-pot procedure afforded 5-bromo pyrimidin-2(1H)-one derivative $\mathbf{3}$ through the intermediate $\mathbf{A}$ that suffer air oxidation leading to the final product. IR spectrum of the pyrimidinone $\mathbf{3}$ showed absorption band at $1653 \mathrm{~cm}^{-1}$ assigned to carbonyl group and its ${ }^{1} \mathrm{H}$ NMR spectrum showed a singlet at $\delta 8.07 \mathrm{ppm}$ indicated the formation of aminic $(\mathrm{NH})$ and aromatic protons were observed at $\delta 8.06-7.06 \mathrm{ppm}$ that confirmed the structure. Also, mass spectrum of $\mathbf{3}$ showed molecular ion peak at $\mathrm{m} / \mathrm{z} 392$ corresponding to its molecular formula $\mathrm{C}_{17} \mathrm{H}_{12} \mathrm{BrClN}_{2} \mathrm{O}_{2}$.

Although the detailed mechanism of above reaction remains not to be fully clarified, the formation of compound $\mathbf{3}$ could be explained by a reaction sequence presented in scheme 2 . We proposed that the reaction proceeded via a reaction sequence of dehydrobromination, Michael type addition, cyclization and dehydration.

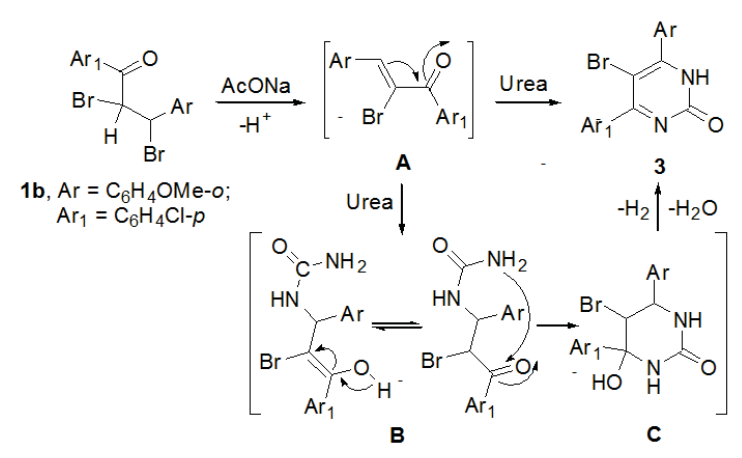

Scheme 2. Proposed mechanism of the synthesis of pyrimidine derivatives.

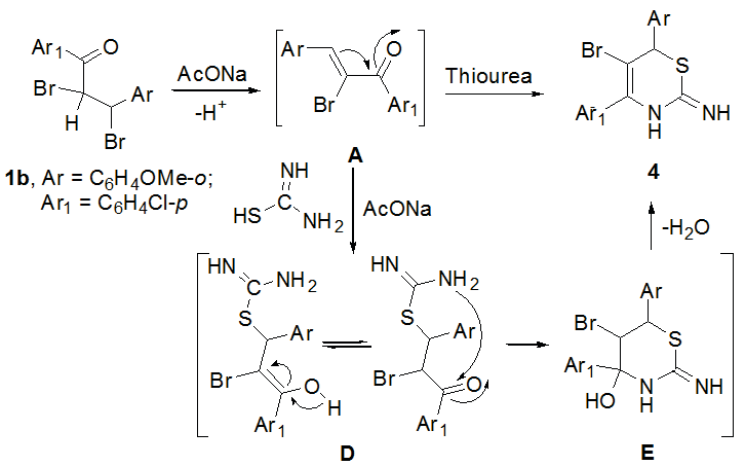

Scheme 3. Proposed mechanism of the synthesis of bromothiazine derivative. 
Furthermore, the kinetic controlled thiazine derivative $\mathbf{4}$ was readily obtained through smooth dehydrobromination of the dibromide $\mathbf{1 b}$ followed by the S-alkylation of thiourea and subsequent thiazine cyclization via losing $\mathrm{H}_{2} \mathrm{O}$ (Scheme 1). The postulated mechanism of formation of the thiazine $\mathbf{4}$ was outlined in details in scheme 3 .

Appearance of absorption bands of $\mathrm{NH}$ groups in the IR spectrum of compound 4 at $3417 \mathrm{~cm}^{-1}$ and its ${ }^{1} \mathrm{H}$ NMR spectrum revealed a singlet at $\delta 3.78(\mathrm{Ar}-\mathrm{CH})$, a multiplet $\delta$ 8.21-7.04 ( $\mathrm{Ar}-\mathrm{H}+\mathrm{D}_{2} \mathrm{O}$ exchangeable $\left.\mathrm{NH}\right)$ as well as the mass spectrum showed ion peaks at $m / z 411\left(\mathrm{M}^{+}+2\right)$ and $410\left(\mathrm{M}^{+}+1\right)$ confirmed its molecular formula.

Refluxing of ethanolic solution of compound $\mathbf{1 b}$ and semicarbazide in presence of AcONa afforded dihydropyrimidin-2(1H)-one derivative 5 (Scheme 1). This was potentiated from spectral analysis which revealed a peaks at $3450(\mathrm{NH}), 3287,3221\left(\mathrm{NH}_{2}\right) 1677,(\mathrm{C}=\mathrm{O}) \mathrm{cm}^{-1}$ and the ${ }^{1} \mathrm{H} \mathrm{NMR}$ spectrum showed a singlet at $\delta 6.60 \mathrm{ppm}\left(\mathrm{D}_{2} \mathrm{O}\right.$ exchangeable $\mathrm{NH}+\mathrm{NH}_{2}$ ). ${ }^{13} \mathrm{CNMR}$ spectrum exhibited two signals at $\delta 55.94$, 54.90 corresponding to methylenic $\mathrm{CH}$ and methoxy groups. MS showed a peaks at $m / z 329,328\left(\mathrm{M}^{+}-\mathrm{Br}\right)$ that confirmed its molecular formula. It seemed that semicarbazide undergo $[3+3]$ cycloaddition with the conjugated intermediate formed upon basic dehydrobromination of compound $\mathbf{1} \mathbf{b}$ followed by dehydration and isomerization resulting in the formation of dihydropyrimidine derivative 5 and none of pyrazole derivative F was obtained (Scheme 4).

Also, one-pot reaction of compounds $\mathbf{1} \mathbf{a}, \mathbf{b}$ with hydrazine hydrate ( $99 \%$ ) / AcONa in ethanol under reflux afforded 4-bromopyrazole derivatives $\mathbf{6 a}$ and $\mathbf{6 b}$. Absence of absorption bands in the latter series for carbonyl group in the IR spectra as well as in the ${ }^{1} \mathrm{H}$ NMR spectra was characteristic for the 4-bromo- $1 \mathrm{H}$-pyrazoles. Thus, Compound 6a were characterized with absorption band at $3445 \mathrm{~cm}^{-1}$ for (NH) group and absence of the carbonyl in the IR spectrum. Its ${ }^{1} \mathrm{H}$ NMR spectrum showed signal at $\delta$ $13.35 \mathrm{ppm}$ attributed to $\mathrm{NH}\left(\mathrm{D}_{2} \mathrm{O}\right.$ exchangeable) and the mass spectrum showed ion peaks at $m / z$ 301, 299 and 222 corresponding to $\left(\mathrm{M}^{+}+2\right),\left(\mathrm{M}^{+}\right)$and $\left(\mathrm{M}^{+}-\mathrm{C}_{6} \mathrm{H}_{5}\right)$, respectively which confirmed its chemical structure. IR spectrum of compound $\mathbf{6 b}$ exhibited absorption band at $3280 \mathrm{~cm}^{-1}$ for (NH). A multiplet at $\delta$ 7.98-7.10 ppm assigned to (Ar-H + $\mathrm{D}_{2} \mathrm{O}$ exchangeable $\mathrm{NH}$ ) in the ${ }^{1} \mathrm{H}$ NMR spectrum and characteristic signals for bromopyrazole showed in ${ }^{13} \mathrm{C}$ NMR spectrum. Also the mass spectrum showed molecular ion peak at $m / z 363$ and $\left(\mathrm{M}^{+}+2\right)$ at 365 that confirmed its molecular formula $\mathrm{C}_{16} \mathrm{H}_{12} \mathrm{BrClN}_{2} \mathrm{O}$. The formation of compounds $6 a$ and $6 b$ could be explained by a reaction sequence presented in scheme 5 .

We proposed that the bromopyrazole derivatives $6 a / 6 b$ were obtained as the result of dehydrobromination, Michael type addition and subsequent intramolecular cyclodehydration.
Using the behavior of $\alpha, \beta$-unsaturated carbonyl system 7 which seemed to be of suitable located functionality towards some nitrogen and/or active methylene nucleophilic reagents was investigated. The mechanistic pathway for these heterocyclization depends upon 1,4-addition followed by intramolecular cyclodehydration and air oxidation in some cases. Thus, when chalcone $7 \mathrm{a}$ was allowed to react with tert-Butyl carbazate, cyclization occurred smoothly by heating under reflux to afford pyrazole 8 as shown in scheme 6 . It presumably that the pyrazole derivative 8 was obtained via $[3+2]$ intermolecular cycloaddition through the $\alpha$ nitrogen of the nucleophilic reagent were added exclusively to $\alpha, \beta$-unsaturated system with simultaneous ring closure. Hence, the structure of compound $\mathbf{8}$ was characterized with absorption bands at $3426(\mathrm{NH}), 1707$ $(\mathrm{C}=\mathrm{O}) \mathrm{cm}^{-1}$ in $\mathrm{IR}$ spectrum and the presence of characteristic singlet at $\delta 10.81,2.18$ and $1.46 \mathrm{ppm}$ in ${ }^{1} \mathrm{H}$ NMR spectrum for $\mathrm{NH}$, methinyl $\mathrm{CH}$ and tert-butyl protons, respectively.

The keeping of $\alpha, \beta$-unsaturated carbonyl derivative $7 a$ with ammonium acetate/AcOH under reflux resulted in pyridine cyclization via the nonisolable $\beta$-amino-ketone followed by $[3+3]$ cyclodehydration to furnish the dihydropyridine derivative, which in turn underwent dehydrogenation giving the final product 9 (Scheme 6).

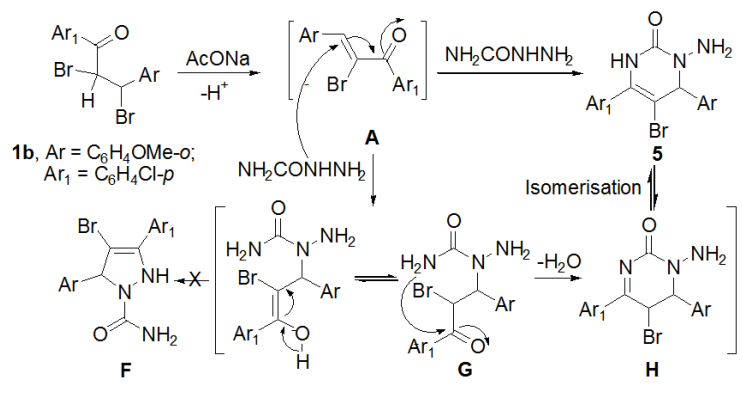

Scheme 4. Proposed mechanism of the synthesis of 5-bromopyrimidine derivatives.

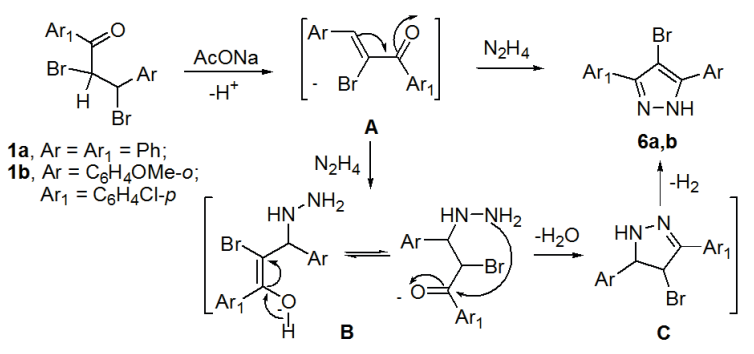

Scheme 5. Proposed mechanism of the synthesis of bromopyrazole derivative. 


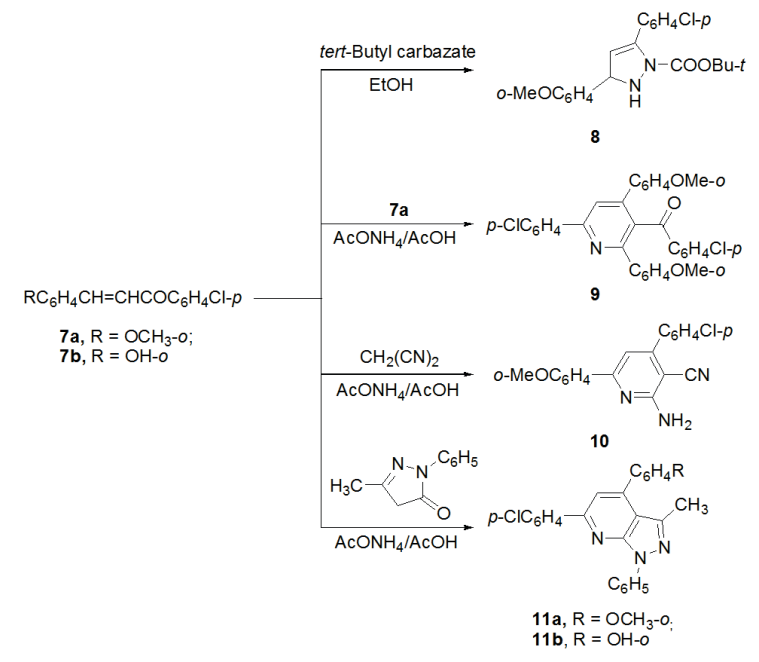

Scheme 6 . Synthesis of some pyrazole, pryridine and pyrazolo[3,4-b]pyridine derivatives.

The analytical and spectral data were consistent with the proposed structure. Thus, the IR spectrum of 9 revealed a peak at $1658 \mathrm{~cm}^{-1}$ of the carbonyl group and the ${ }^{1} \mathrm{H}$ NMR spectrum showed a multiplet at $\delta$ 8.27-7.09 indicating the $\mathrm{Ar}-\mathrm{H}$ and $\mathrm{CH}$ pyridine protons and a singlet at $\delta 3.83 \mathrm{ppm}$ according to $2 \mathrm{OCH}_{3}$ protons.

The high yield of $\alpha, \beta$-unsaturated system of type 7 encouraged us again to study their further reactivities towards cyano methylene reagents. Pyridine of type $\mathbf{1 0}$ was formed upon the addition of malononitrile to ketonic derivative $\mathbf{7}$ in the presence of ammonia source. Thus, malononitrile added its nucleophilic carbon to electrophilic carbon of 7a producing acyclic Michael type adduct that cyclizes intramolecularly in presence of $\mathrm{AcONH}_{4} / \mathrm{AcOH}$ producing pyridin-3-carbonitrile 10 . While, $\alpha, \beta$-unsaturated system 7a,b when allowed to react with 5-methyl-2-phenyl-2,4-dihydro-3H-pyrazol-3-one afforded pyrazolo[3,4-b]pyridine of type $\mathbf{1 1}$ (Scheme 6). The analytical and spectral data of the obtained products were in agreement with the assigned structures. Thus, the ${ }^{1} \mathrm{H}$ NMR spectrum of 10 showed beside the expected signals of the pyridine moiety, a singlet at $\delta 3.36 \mathrm{ppm}$ corresponding to $\mathrm{D}_{2} \mathrm{O}$ exchangable, $\mathrm{NH}_{2}$ group, a multiplet at $\delta 8.12-6.93 \mathrm{ppm}$ including the aromatic protons with $\mathrm{CH}$ pyridine and the IR spectrum exhibited peak at $2217 \mathrm{~cm}^{-1}$ of the cyano group.

Also, the ${ }^{1} \mathrm{H}$ NMR spectrum of product 11a (as an example) showed beside the expected signals of the pyrazolopyridine moiety, a multiplet at $\delta$ 8.27-7.09 ppm including the aromatic protons with $\mathrm{CH}$ pyridine and the IR spectrum exhibited peak at $1600(\mathrm{C}=\mathrm{N}) \mathrm{cm}^{-1}$ and absence of carbonyl groups. The mass spectrum of product 11a revealed molecular ion peak at $m / z=426$ that confirmed the postulated structure.

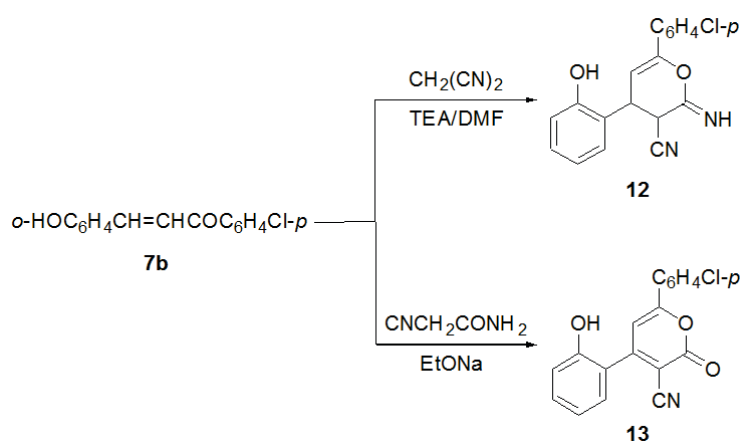

Scheme 7. Synthesis of pyrane 3-carbonitrile derivatives.

The reaction of $\alpha, \beta$-ketonic derivative $7 \mathbf{b}$ with malononitrile in DMF/TEA afforded 2-imino-3,4-dihydro-2H-pyran-3-carbonitrile derivative $\mathbf{1 2}$ (Scheme 7). This reaction presumably proceeded via Michael addition followed by intramolecular cyclization producing pyran derivative $\mathbf{1 2}$. The IR spectrum of compound $\mathbf{1 2}$ revealed the absence of carbonyl group and showed absorption bands at 3429, 3235, 2202 and $1601 \mathrm{~cm}^{-1}$ for phenolic $\mathrm{OH}$, iminic $\mathrm{NH}, \mathrm{CN}$ groups as well as in the MS showed ion peaks at $m / z 324\left(\mathrm{M}^{+}\right)$and $323\left(\mathrm{M}^{+}-1\right)$ confirmed its molecular formula.

Cycloaddition of cyanoacetamide with the chalcone 7b in ethanolic EtONa solution afforded an Michael type adducts intermediate which in turn underwent basic cyclization followed by dehydrogenation producing pyran-3carbonitrile derivative $\mathbf{1 3}$ (Scheme 7). The analytical and spectral data was consistent with the proposed structure. Thus, the IR spectrum of compound $\mathbf{1 3}$ showed absorption bands at 3409, 2226, 1771, $1614 \mathrm{~cm}^{-1}$ for $\mathrm{OH}, \mathrm{CN}, \mathrm{C}=\mathrm{O}$ and $\mathrm{C}=\mathrm{C}$ groups, respectively. Its ${ }^{1} \mathrm{H}$ NMR spectrum showed signal at $10.10 \mathrm{ppm}$ assigned for $\mathrm{OH}$ group as well as in the MS showed ion peak at $m / z 324\left(\mathrm{M}^{+}+1\right)$, and $323\left(\mathrm{M}^{+}\right)$confirmed its molecular formula.

Also, chromenopyridine 14 was prepared by nucleophilic reaction of malonamide with $\mathbf{7 b}$ forming the nonisolable phenol $A$ that undergo $\mathrm{NH}_{3}$ losing by intramolecular cyclization to give pyran ring (Scheme 8). Structure of $\mathbf{1 4}$ assigned by IR, ${ }^{1} \mathrm{H}$ NMR and mass spectral data. In its IR spectrum, there are four bands assignable to $\mathrm{NH}, 2 \mathrm{CO}, \mathrm{C}=\mathrm{C}$ groups at 3433, 1777, 1638 and $1616 \mathrm{~cm}^{-1}$, respectively. ${ }^{1} \mathrm{H}$ NMR spectrum showed deshielded singlet at $12.42 \mathrm{ppm}$ attributed for $\mathrm{NH}\left(\mathrm{D}_{2} \mathrm{O}\right.$ exchangable) and aromatic protons were observed at $\delta 8.50-7.36 \mathrm{ppm}$.

The synthesis of 1-[2-butyryl-5-(4-chlorophenyl)-3(2-hydroxyphenyl)-2,3-dihydro-1H-pyrazol-1-yl]-1-butanone derivative 15 was achieved by intermolecular cycloaddition of hydrazine hydrate in the presence of butyric acid that form acylated pyrazole. Hence, refluxing of $\alpha, \beta$-unsaturated derivative $\mathbf{7 b}$ in presence of hydrazine hydrate $99 \%$ in butyric acid yield the $\mathrm{N}$-butanoyl product $\mathbf{1 5}$ (Scheme 8). 


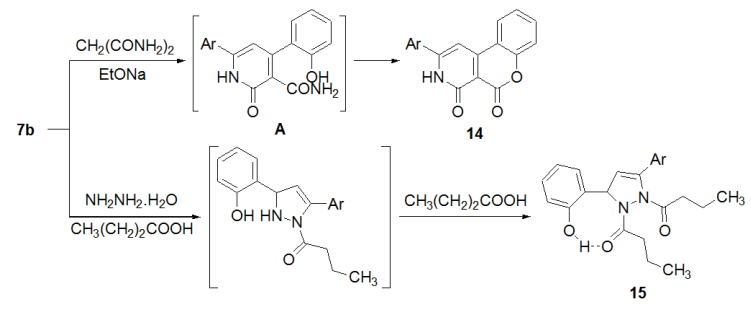

Scheme 8. Utility o-hydroxy arylidene derivatives in synthesis of condensed heterocycles.

The analytical and spectral data were consistent with the proposed structure. Thus, the IR spectrum of $\mathbf{1 5}$ revealed a peak at $3226(\mathrm{OH})$ and $1638 \mathrm{~cm}^{-1}$ of the carbonyl groups and the ${ }^{1} \mathrm{H}$ NMR spectrum showed a singlet at $\delta 9.62 \mathrm{ppm}$ assigned for $\mathrm{OH}$ group, double doublet at $\delta 5.67$ according to enaminic $\mathrm{CH}$ group of pyrazole, double doublet at $\delta 3.02$ indicating $\mathrm{CH}$ methylenic and a characteristic signals for the propyl groups. MS spectrum of $\mathbf{1 5}$ showed molecular ion peak at $m / z=413$.

\section{Biological Activity}

The compounds bearing Pyrimidine, pyridine and/or pyrazole nucleus are well known to exhibit versatile range of biological activities such as anti-diabetic activities. ${ }^{[12-16]}$ From the structure-activity relationships, it is revealed that the selected group of heterocyclic skeletons is important for anti-diabetic studies, which supports the previous results. For instance, the novel compounds 5, 8, 10, 11a and 11b shared similar chemical features and functional groups, such as the presence of hydroxyl and methoxy groups were evaluated for their potential $\alpha$-glucosidase inhibitory activity. The results are presented in Table 1 . The activity comparison and the structure correlation of the tested group of the novel compounds had shown that these potencies paralleled the pyrazole moiety.

The pyrazole derivative 8 of the tested compounds were found to have less inhibitory ( $\alpha$-glucosidase inhibitory) activity than a commercial anti-hyperglycemic drug, acarbose $\left(I C_{50}=12.87 \mu \mathrm{M}\right)$. The pyrazolo[3,4-

Table 1. Effect of compounds 5, 8, 10, 11a, 11b and acarbose on the anti-diabetic potential.

\begin{tabular}{cc}
\hline Compound & $\mathrm{IC}_{50} / \mu \mathrm{g} \mathrm{L}$ \\
\hline 5 & 60.67 \\
8 & 33.20 \\
10 & $>500$ \\
$11 \mathrm{a}$ & 185.07 \\
$11 \mathrm{~b}$ & 13.80 \\
Acarbose & 12.87 \\
\hline
\end{tabular}

b]pyridin-4-yl]phenol derivative 11b was the most potent inhibitor $\left(\mathrm{IC}_{50}=13.80 \mu \mathrm{M}\right)$. Also, It was noted that the introduction of a 2-hydroxyphenyl group at position 4 on the condensed pyrazolopyridine moiety increased the activity (compound 11b), while the introduction of a 2methoxyphenyl group at position 4 on the condensed pyrazolopyridine moiety decreased the activity (compound 11a), except for isolated pyrazole (Compound 8). These results indicate that hydroxylation of the condensed pyrazolopyridine rings is important for $\alpha$-glucosidase inhibitory activity.

The $\mathrm{IC}_{50}$ value was defined as the concentration of alpha-glucosidase inhibitor to inhibit $50 \%$ of its activity under the assayed conditions. All determinations were carried out in triplicate manner and values are expressed as the mean $\pm \mathrm{CD}$. Anti-diabetic activity of the tested compounds was depicted with $\mathrm{IC}_{50}$ value in Table 1.

\section{CONCLUSIONS}

In this work some novel condensed pyrimidine, pyrazole and pyridine derivatives were synthesized and assayed for their anti-diabetic inhibitory. The experimental work involves the synthesis of $\alpha, \beta$-unsaturated carbonyls and $\alpha, \beta$-dibromocarbonyls which was then heteroannelated with various 1,2; 1,3-bidentate nitrogen and carbon nucleophiles. Correlations are useful because they can indicate a predictive relationship that can be exploited in practice. Comparing of the anti-diabetic activity of the tested group of new compounds and its analogous described in the literature, ${ }^{[39-41]}$ it is obvious that the highest activity might be attributed to the presence of pyrazolo[3,4-b]pyridine moiety bearing $2-\mathrm{HOC}_{6} \mathrm{H}_{4}$ group.

Acknowledgment. The authors thank Regional Center for Mycology and Biotechnology, Al-Azhar University, Cairo, Egypt for offering the needed facilities for running the antimicrobial activity assays and $\mathrm{Dr}$ Jamal A. Ahmed for assistance in the early stages of this program.

\section{REFERENCES}

[1] Y. H. Ju, R. S. Varma, Tetrahedron Lett. 2005, 46, 6011.

[2] E. J. Noga, G. T. Barthalmus, M. K. Mitchell, Cell Biol. Int. Rep. 1986, 10, 239.

[3] F. A. Luzzio, M. T. Wlodarczyk, Tetrahedron Lett. 2009, 50, 580.

[4] F. Gomez-Contreras, P. Navarro, J. Heterocycl. Chem. 1979, 16, 1035.

[5] M. M. Herav, B. Baghernejad, H. A. Oskooie, Tetrahedron Lett. 2009, 50, 767.

[6] S. Madapa, Z. Tusi, A. Mishra, K. Srivastava, S. K. Pandey, R. Tripathi, S. K. Puri, S. Batra, Bioorg. Med. Chem. 2009, 17, 222. 
[7] N. Fujiwara, T. Nakajima, Y. Ueda, H. Fujita, H. Kawakami, Bioorg. Med. Chem. 2008, 16, 9804.

[8] F. Gomez-Contreras, M. Lora-Tamayo, P. Navarro, M. Pardo, Tetrahedron 1978, 34, 3499.

[9] W. Eberbach, H. Fritz, N. Labe, Angew. Chem. Int. Ed. 1998, 27, 568.

[10] N. Župančić, Ž. Ban, J. Matić, D. Saftić, L. GlavašObrovac, B. Žinićb, Croat. Chem. Acta 2015, 88, 43.

[11] Y. V. Popova, D. V. Sakhnenko, I. V. Arbuzova, V. A. Osyanin, D. V. Osipov, Y. N. Klimochkin, Chem. Heterocyc. Compd. 2016, 52, 803.

[12] N. Azas, P. Rathelot, S. Djekou, F. Delmas, A. Gellis, C. D. Giorgio, P. Vanelle, P. Timon-David, Farmaco 2003, 58, 1263.

[13] A. Agarwal, K. Srivastava, S. K. Puri, P. M. S. Chauhan, Bioorg. Med. Chem. 2005, 13, 4645.

[14] M. Johar, T. Manning, D. Y. Kunimoto, R. Kumar, Bioorg. Med. Chem. 2005, 13, 6663.

[15] S. Deshmukh, K. Dingore, V. Gaikwad, M. Jachak, J. Chem. Sci. 2016, 128, 1459.

[16] H. W. Lee, B. Y. Kim, J. B. Ahn, S. K. Kang, J. H. Lee, J. S. Shin, S. K. Ahn, S. J. Lee, S. S. Yoon, Eur. J. Med. Chem. 2005, 40, 862.

[17] F. Xie, H. Zhao, L. Zhao, L. Lou, Y. Hu, Bioorg. Med. Chem. Lett. 2009, 19, 275.

[18] M. A. Kaldrikyan, L. A. Grigoryan, V. A. Geboyan, F. G. Arsenyan, G.M. Stepanyan, B. T. Garibdzhanyan, Pharm. Chem. J. 2000, 34, 521.

[19] B. Kumar, B. Kaur, J. Kaur, A. Parmar, R. D. Anand, H. Kumar, Indian J. Chem. B 2002, 41, 1526.

[20] A. L. S. Rodrigues, J. M. Rosa, V. M. Gadotti, E. C. Goulart, M. M. Santos, A. V. Silva, B. Sehnem, L. S. Rosa, R. M. Gonçalves, R. Corrêa, A. R. S. Santos, Pharmacol. Biochem. Be. 2005, 82, 156.

[21] J. Tani, Y. Yamada, T. Oine, T. Ochiai, R. Ishida, I. Inoue, J. Med. Chem. 1979, 22, 95.

[22] Z.-L. Ren, J. Zhang, H.-D. Li, M.-J. Chu, L.-S. Zhang, X.K. Yao, Y. Xia, X.-H. Lv, H.-Q. Cao, Chem. Pharm. Bull. 2016, 64, 1755.
[23] C. S. Reddy, M. V. Devi, M. Sunitha, A. Nagaraj, Chem. Pharm. Bull. 2010, 58, 1622.

[24] Y. H. Seham, Molecules 2013, 18, 2683.

[25] H. S. Shailesh, S. P. Pankaj, Chem. Sci. Trans. 2012, 1, 632.

[26] E. Palaska, M. Aytemir, I. T. Uzbay, D. Erol, Eur. J. Med. Chem. 2001, 36, 539.

[27] R. Y. Prasad, L. A. Rao, L. Prasoona, K. Murali, R. P. Kumar, Bioorg. Med. Chem. Lett. 2005, 15, 5030.

[28] E. Palaska, D. Erol, R. Demirdamar, Eur. J. Med. Chem. 1996, 31, 43.

[29] Z. Ozdemir, B. H. Kandilici, B. Gumucel, U. Calis, A. A. Bilgin, Eur. J. Med. Chem. 2007, 42, 373.

[30] P. J. Jainey, I. K. Bhat, J. Young Pharm. 2012, 4, 82.

[31] M. F. El Shehry, R. H. Swellem, S. M. Abu-Bakr, E. M. El-Telbani, Eur. J. Med. Chem. 2010, 45, 4783.

[32] E. Abdelghani, Heterocycles 2001, 55, 2413.

[33] E. Abdelghani, J. Chem. Res. 1999, S, 174; M 1135.

[34] M. G. Assy, E. Abdelghani, Pol. J. Chem. 1995, 69, 685.

[35] M. G. Assy, H. H. Sayed, A. H. Moustafa, M. N. Yousif, M. A. El-Hallim, Phosphorus Sulfur 2008, 183, 2318.

[36] E. Abdelghani, S. A. Said, M. G. Assy, A. M. Abdel Hamid, J. Iran. Chem. Soc. 2015, 12, 1809.

[37] E. A. Soylem, M. G. Assy, G. M. Morsi, Acta Chim. Slov. 2016, 63, 609.

[38] E. Abdelghani, S. A. Said, M. G. Assy, A. M. Abdel Hamid, Arabian J. Chem. 2017, 10, S2926.

[39] E. Hernández-Vázquez, S. Salgado-Barrera, J. J. Ramírez-Espinosa, S. Estrada-Soto, F. HernándezLuis, Bioorg. Med. Chem. 2016, 24, 2298.

[40] E. Hernández-Vázquez, H. Ocampo-Montalban, L. Cerón-Romero, M. Cruz, J. Gómez-Zamudio, G. Hiriart-Valencia, R. Villalobos-Molina, A. FloresFlores, Eur. J. Pharmacol. 2017, 803, 159.

[41] K. Takao, M. Yamashita, A. Yashiro, Y. Sugita, Chem. Pharm. Bull. 2016, 64, 1203.

[42] E. Apostolidis, Y. I. Kwon, K. Shetty, Innov. Food Sci. Emerg. 2007, 8, 46. 